\title{
Perceived Risk and Distress related to COVID-19: Comparing Healthcare versus non-Healthcare Workers of Pakistan
}

1 Adeel Abid $^{1, \Omega}$, Hania Shahzad ${ }^{1, \Omega}$, Hyder Ali Khan ${ }^{2}$, Suneel Piryani ${ }^{2}$, Areeba Raza Khan ${ }^{3}$,

2 Fauziah Rabbani ${ }^{2,3}$,*

$3 \quad{ }^{1}$ Medical College, Aga Khan University, Karachi, Pakistan

$4 \quad{ }^{2}$ Department of Community Health Sciences, Aga Khan University, Karachi, Pakistan

$5 \quad{ }^{3}$ Office of Research \& Graduate Studies, Aga Khan University, Karachi, Pakistan

$6 \quad \mathbf{\Omega}$ Authors have made equal contribution

7 * Correspondence:

8 Fauziah Rabbani

9 fauziah.rabbani@aku.edu 


\section{Abstract}

\section{Background}

12 Healthcare workers (HCWs) find themselves susceptible to contracting COVID-19 or being the

13 source of exposure for their family members. This puts them at a high risk of psychological distress

14 which may compromise patient care. In this study we aim to explore the risk perceptions and

15 psychological distress between HCWs and non-healthcare workers (NHCWs) in Pakistan.

\section{Methods}

17 A cross-sectional study was conducted in Pakistan using an online self-administered questionnaire.

18 Respondents were categorized into HCWs (completed or aspiring to complete education in Medicine

19 or allied fields) and NHCWs. HCWs were further categorized into front-line (direct patient care) and

20 back-end HCWs.

\section{Results}

22 Data from 1406 respondents (507 HCWs and 899 NHCWs) was analyzed. No significant difference

23 was observed between HCWs and NHCWs' perception of susceptibility and severity towards

24 COVID-19. Healthcare graduates perceived themselves (66\% students vs. $80 \%$ graduates, p-value

250.011 ) and their family (67\% students vs. $82 \%$ graduates, p-value 0.008 ) to be more susceptible to

26 COVID-19 than the healthcare students. Frontline HCWs perceived themselves (83\% frontline vs.

$2770 \%$ back-end, p-value 0.003 ) and their family ( $84 \%$ frontline vs. $72 \%$ back-end, p-value 0.006 ) as

28 being more susceptible to COVID-19 than back-end healthcare professionals. Over half of the

29 respondents were anxious (54\% HCWs and 55\% NHCWs). Female gender, younger age and having

30 COVID-19 related symptoms had a significant effect on the anxiety levels of both HCWs and 31 NHCWs. 
medRxiv preprint doi: https://doi.org/10.1101/2020.10.23.20218297; this version posted October 27, 2020. The copyright holder for this preprint (which was not certified by peer review) is the author/funder, who has granted medRxiv a license to display the preprint in perpetuity. It is made available under a CC-BY-NC-ND 4.0 International license.

\section{Conclusion}

33 Frontline HCWs, healthcare students, young people, females and individuals with lower income were

34 at a higher risk of psychological distress due to the pandemic. Government policies should thus be

35 directed at ensuring the mental well-being of frontline HCWs, and improving their satisfaction in

36 order to strengthen health care delivery system.

37 Keywords: COVID-19, Healthcare workers, Risk perception, Anxiety, Depression, Psychological

38 distress 
medRxiv preprint doi: https://doi.org/10.1101/2020.10.23.20218297; this version posted October 27, 2020. The copyright holder for this preprint (which was not certified by peer review) is the author/funder, who has granted medRxiv a license to display the preprint in perpetuity.

It is made available under a CC-BY-NC-ND 4.0 International license .

\section{Introduction}

40 COVID-19 has grappled the world since its first case was diagnosed in Wuhan, China (1). This has

41 resulted in a global socio-economic crisis and challenged healthcare systems throughout the world.

42 According to the World Health Organization (WHO), this is the worst pandemic the organization has

43 seen in its 75-year long history (2). As of $25^{\text {th }}$ July 2020, Pakistan has officially reported 270,113

44 confirmed cases with near 5,822 confirmed deaths (3). The pandemic has also taken an economic toll

45 on the population due to the government imposing a nation-wide lockdown from March to May,

46 2020. According to a Gallup Survey reported in April 2020, 6.9 million households claimed to have

47 reduced the number or size of meals for some family members while nearly 1 in 4 Pakistanis said that

48 they were relying on less preferred and less expensive food items to cover their basic household

needs. Furthermore, almost 1 in 5 people in the country say that they had to lean on their savings to

cover basic household needs (4). A major concern in the country is the impact of COVID-19 on

51 healthcare workers (HCWs), who are at a high risk during novel disease outbreaks. HCWs around the

world are at the forefront in screening, quarantining, and managing actual and suspected COVID-19

53 patients, creating awareness about risks, and advocating for preventive measures (5). Consequently,

54 fear of contracting the disease is likely to put them under greater stress when compared to the general

55 population.

56 Experience from severe acute respiratory syndrome (SARS) and H1N1 epidemics underlines that the

57 psychological strain on healthcare professionals, especially those working on the frontlines is

58 significant $(6,7)$. In these stressful times, HCWs are risking high morbidity and mortality due to the

nature of their job. Demands of the job may negatively impact the emotional and psychological well-

60 being of those working on the front line. Moreover, as compared to the general public, HCWs face

61 more personal worries such as comparatively greater infection risk to self and others and concerns 
medRxiv preprint doi: https://doi.org/10.1101/2020.10.23.20218297; this version posted October 27, 2020. The copyright holder for this preprint (which was not certified by peer review) is the author/funder, who has granted medRxiv a license to display the preprint in perpetuity. It is made available under a CC-BY-NC-ND 4.0 International license .

62 regarding the well-being of family members. Increased anxiety and depression among frontline

63 healthcare professionals is a common feature in epidemics $(8,9)$. Moreover, there are disparities in

64 terms of psychological impact due to COVID-19 within HCWs depending on their level of patient

65 care. In a study conducted in Singapore the psychological distress, depression, anxiety, and stress

66 experienced by health care workers during the COVID-19 outbreak, frontline nurses had significantly

67 lower vicarious traumatization scores than non-frontline nurses and the general public (10). Another

68 recent study among healthcare professionals in a tertiary infectious disease hospital for COVID-19 in

69 China also revealed a high incidence of anxiety and stress disorders among frontline medical staff,

70 with nurses having a higher incidence of anxiety than doctors (11).

71 The scale of the current health crisis is a bigger concern in a resource-limited country like Pakistan,

72 where it may significantly compromise the quality of care and health care services. These

73 unprecedented times call for an increased need to gauge the knowledge and protective behaviors of

74 people at different levels of health care services. Unduly high anxiety levels and poor-risk

75 perceptions often result in barriers to healthcare providers' willingness and ability to work and

76 constitute an important component in policy-related decisions $(12,13)$. While data is limited on the

77 impact of COVID-19 with regards to barriers to working, it is indicated that healthcare providers are

78 likely to suffer from high levels of anxiety and post-traumatic stress disorders (14).

79 Prevention remains the mainstay in the treatment and containment of the pandemic, requiring people

80 at large to practice COVID-19 mitigating behaviors. Significant efforts hence need to be undertaken

81 to strengthen beliefs about the disease in the population including the severity and susceptibility of

82 threat so that people are more likely to take the needed actions to reduce the damage caused by the

83 disease. As a result, it becomes important to study these key indicators to evaluate the public sense 
medRxiv preprint doi: https://doi.org/10.1101/2020.10.23.20218297; this version posted October 27, 2020. The copyright holder for this preprint (which was not certified by peer review) is the author/funder, who has granted medRxiv a license to display the preprint in perpetuity.

It is made available under a CC-BY-NC-ND 4.0 International license .

84 of threat to health, leading to the development of strategies for the general population and medical

85 staff during COVID-19.

86 As psychological morbidity including depression, perceived stress and anxiety can compromise the

87 social, emotional, psychological and physical functioning of a human being, the healthcare

88 community is thought to be especially vulnerable. Psychological morbidity especially in the

89 healthcare community may compromise patient care. It is therefore essential to carefully gauge the

90 level of perceived susceptibility, severity, anxiety and subsequent response to COVID-19 between

91 HCWs and non-healthcare workers (NHCWs). Identifying vulnerable areas and populations for

92 psychological distress will help in strengthening health service delivery with targeted interventions.

93 In this study we describe perceived severity, susceptibility and anxiety levels of HCWS in

94 comparison to NHCWs. Furthermore, we explore vulnerable sub groups in the healthcare population

95 with regards to training status, age, gender, income levels and level of patient care.

\section{Materials and Methods}

\section{Study Design}

98 A cross-sectional online survey was carried out in May 2020 through the social media channels of

99 Aga Khan University (AKU), Pakistan, which included Facebook, Twitter, and LinkedIn. The survey

100 link was also reposted on the Facebook page of Aga Khan University Hospital (AKUH), Pakistan.

\section{Study Participants}

102 A convenience sampling strategy was used to enroll participants in the study. The online survey link

103 remained active for two weeks. A total of 1405 respondents (507 HCWs and 899 NHCWs) filled the

104 questionnaires. People aged 18 or above, residing in Pakistan for at least five days a week over the

105 last month, with access to the internet and willing to participate in the survey were included in the 
medRxiv preprint doi: https://doi.org/10.1101/2020.10.23.20218297; this version posted October 27, 2020. The copyright holder for this preprint (which was not certified by peer review) is the author/funder, who has granted medRxiv a license to display the preprint in perpetuity.

It is made available under a CC-BY-NC-ND 4.0 International license.

106

107

108

109

110

111

112

113

114

115

116

117

118

study. The questionnaire was supposed to be filled once by each participant. Participants who could not respond to the study tool in either English or Urdu and participants who reported having filled the questionnaire at least once before were excluded from the study.

Respondents were categorized into NHCWs and HCWs. Those without basic (Bachelor level) training in any health or allied field were categorized as NHCWs whereas respondents having a formal training (students or graduates) in Medicine, Nursing, Pharmacy, Dentistry, Physiotherapy, Laboratory Technology or Allied Health Sciences including but not limited to homeopathy and Hikmat (a system of alternative medicine that involves the use of herbal remedies, dietary practices, and alternative therapies and addresses the prevention and treatment of disease) were categorized as HCWs. HCWs were further categorized into front-line and back-end HCWs. Front-line HCWs included all those professionals who are involved in direct patient care. Back-end HCWs included those who are currently not involved in direct clinical patient care including but not limited to undergraduate students of Medicine and Nursing and HCWs employed in the fields of Pharmacy, Dentistry, Physiotherapy, Laboratory Technology, Allied Health Sciences or others.

\section{Data Collection}

Data was collected through two online self-administered semi-structured questionnaires (Questionnaire A and B). Questionnaire A was for NHCWs and Questionnaire B was for HCWs. Both questionnaires were developed on Google Forms. The questionnaires were adapted from the survey tool used in a similar study conducted in Hong Kong (21). Questionnaires A and B contained mostly identical questions, with a few additional questions in Questionnaire B related to HCWs' field of study, training, place of work, perception about governmental measures, severity of COVID-19 as compared to other diseases and if they had acquired specific training related to COVID-19 in their respective organizations. Respondents, were asked about their demographics including gender, age, 
medRxiv preprint doi: https://doi.org/10.1101/2020.10.23.20218297; this version posted October 27, 2020. The copyright holder for this preprint (which was not certified by peer review) is the author/funder, who has granted medRxiv a license to display the preprint in perpetuity.

It is made available under a CC-BY-NC-ND 4.0 International license .

level of education, household income, permanent city of residence, and travel history followed by

130 their health status in the past 14 days and whether they experienced any symptoms of illness.

131 Next, they were asked to rate the severity of the symptoms caused by COVID-19 and their perceived

132 chance of survival if infected with COVID-19. Responses were captured using a five-point Likert

133 scale. Subsequently, information exposure was probed by asking respondents about the sources from

134 which they obtain information about COVID-19, and how reliable they deemed those sources to be.

135 This was followed by questions on how likely one considered themselves and their families to be

136 infected with COVID-19 if no preventive measures were taken. Participants' anxiety and depression

137 levels were assessed using the validated Hospital Anxiety and Depression Scale (HADS). This scale

138 was used in a study conducted in Hong Kong for assessing anxiety related to COVID-19 $(15,16)$. The

139 possible minimum score for anxiety and depression is 0 and the maximum is 21 . A score of 8 or

140 above indicates anxiety. Respondents were also asked about the psychological impact of COVID-19

141 on their job, personal life, sleep, and eating habits.

\section{Data Analysis}

143 Data collected from respondents was directly stored in Google Spreadsheets and later imported to

144 Microsoft Excel and Statistical Package for the Social Sciences (SPSS) Version 21 (IBM Corp). Data

145 was cleaned, coded, and analyzed using SPSS. A descriptive analysis was performed and results were

146 tabulated as numbers (percentages) for qualitative variables and mean ( \pm standard deviation) for

147 quantitative variables. The Independent t-test or Mann Whitney U test or Pearson Chi-square test was

148 applied to assess the differences between the groups' (healthcare vs. NHCWs, healthcare students vs.

149 graduates, frontline vs. back-end HCWs) perception of susceptibility and severity towards COVID-

15019 , anxiety and depression level, the psychological impact of COVID-19, adoption of precautionary

151 measures, reliability of information sources, and satisfaction with government measures. Bivariate 
medRxiv preprint doi: https://doi.org/10.1101/2020.10.23.20218297; this version posted October 27, 2020. The copyright holder for this preprint (which was not certified by peer review) is the author/funder, who has granted medRxiv a license to display the preprint in perpetuity.

It is made available under a CC-BY-NC-ND 4.0 International license .

152 and multivariate binary logistic regression analyses were performed to identify predictors (age,

153 gender, household income, and presence of symptoms) of anxiety and depression among HCWs and

154 NHCWs. Initially, in bivariate analysis, a single predictor at a time was entered and crude odds ratio

$155(\mathrm{OR})$ and $95 \%$ confidence intervals (CI) were subsequently computed. A multivariate analysis, with

156 all predictors entered at the same time, was completed to adjust for the effect of confounding, and

157 adjusted OR and 95\% CI were computed. All statistical tests were two-sided and a p-value of $\leq 0.05$

158 was considered to be statistically significant.

\section{Ethical Consideration}

160 Ethical approval was obtained from the Ethical Review Committee (ERC) of the Aga Khan

161 University, Pakistan. Participants were asked to present their consent at the beginning of the survey

162 and were free to withdraw at any stage.

\section{Results}

164 Data from 1406 respondents (507 HCWs and 899 NHCWs) was analyzed. Majority of the

165 respondents were males (53\% HCWs and 72\% NHCWs), below the age of 35 years (78\% HCWs and

$16661 \%$ NHCWs), were residents of Karachi (49\% HCWs and 50\% NHCWs), and had a household

167 income of $\leq$ PKR 40,000 (22\% HCWs and 27\% NHCWs) (Refer to Table 1). More than half of the

168 HCWs (54\%) belonged to the field of Medicine and 36\% were currently working in a hospital, ward

169 or a clinic (Refer to Table 2).

\section{Perceived severity and susceptibility for COVID-19}

171 No significant difference was observed between HCWs and NHCWs' perception of susceptibility

172 and severity towards COVID-19. About three-fourths of the respondents perceived that they $(75 \%$

173 HCWs and 71\% NHCWs) and their families (77\% HCWs and 71\% NHCWs) might get sick if they 
medRxiv preprint doi: https://doi.org/10.1101/2020.10.23.20218297; this version posted October 27, 2020. The copyright holder for this preprint (which was not certified by peer review) is the author/funder, who has granted medRxiv a license to display the preprint in perpetuity.

It is made available under a CC-BY-NC-ND 4.0 International license.

174 do not take preventive measures. Similarly, several respondents considered the symptoms of COVID-

17519 (if infected) as serious (46\% HCWs and 38\% NHCWs). Furthermore, most respondents thought

176 that one could survive a COVID-19 infection (HCWs 70\% and NHCWs 66\%). However, a

177 statistically significant difference was seen between the healthcare students' and graduates'

178 perception of susceptibility and severity towards COVID-19. Healthcare graduates perceived

179 themselves (66\% students vs. $80 \%$ graduates, p-value 0.011$)$ and their family (67\% students vs. $82 \%$

180 graduates, p-value 0.008) to be more susceptible to COVID-19 than the healthcare students.

181 Similarly, compared to students, more graduates perceived the disease to be severe (p-value 0.040).

182 A significant difference was also seen between frontline and back-end HCWs' perception of

183 susceptibility and severity towards COVID-19. Frontline HCWs perceived themselves (83\% frontline

184 vs. $70 \%$ back-end, p-value 0.003$)$ and their family ( $84 \%$ frontline vs. $72 \%$ back-end, p-value 0.006$)$

185 as being more susceptible to COVID-19 than back-end HCWs. However, compared to those on the

186 frontline, more back-end HCWs perceived the disease to be severe (p-value 0.045) (Refer to Table

$1873)$.

188 Psychological Distress in HCWs and NHCWs:

189 Over half of the respondents were found to be either anxious (54\% HCWs and 59\% NHCWs) or

190 depressed (54\% HCWs and 57\% NHCWs) as indicated by the HADS scores. No significant

191 difference was seen in the anxiety and depression levels of HCWs and NHCWs. However, the

192 incidence of depression was significantly higher among healthcare students compared to healthcare

193 graduates (Mean (SD): 8.40 (3.45) in students 7.72 (3.80) in graduates, p-value 0.047). Around 62\%

194 of healthcare students and $49 \%$ of graduates had depression. A statistically significant difference was

195 noted between frontline and back-end HCWs' perception about the impact of COVID-19 on their

196 personal life (75\% frontline vs. $58 \%$ back-end HCWs, p-value <0.001). However, no significant 
medRxiv preprint doi: https://doi.org/10.1101/2020.10.23.20218297; this version posted October 27, 2020. The copyright holder for this preprint (which was not certified by peer review) is the author/funder, who has granted medRxiv a license to display the preprint in perpetuity.

It is made available under a CC-BY-NC-ND 4.0 International license .

difference was reported between HCWs' and NHCWs' perceived impact of COVID-19 on their jobs,

198 personal life, sleeping pattern, and eating habits (Refer to Table 4).

199 Predictors of Psychological Distress in HCWs and NHCWs:

200 Gender, age, and presence of symptoms had significant positive associations with anxiety among

201 HCWs. Female HCWs were nearly twice as likely to be anxious than the male HCWs (aOR: 2.34,

202 95\% CI: 1.37-3.99, p-value 0.002). HCWs of younger age (25-34 years) (aOR 3.44, 95\% CI: $1.30-$

203 9.09, p-value: 0.013) were nearly three times more likely to have anxiety than HCWs of 55 years or

204 above. HCWs having COVID-19 related symptoms were 2.09 times more likely to have anxiety than

205 HCWs without symptoms (aOR: 2.09, 95\% CI: 1.01-4.32, p-value: 0.046) (Refer to table 5).

206 Similarly, gender, age, household income, and presence of symptoms were positively associated with

207 anxiety among NHCWs. Female NHCWs were 1.62 times more likely to have anxiety than male

208 NHCWs (aOR: 1.62, 95\% CI: 1.12-2.35, p-value 0.010). NHCWs of younger age (25-34 years) (aOR

$2092.84,95 \%$ CI: $1.75-4.62$, p-value: <0.001) were nearly three times more likely to be anxious than

210 NHCWs of 55 years or above. NHCWs having income level of 60,001-120,000 PKR were 2.22 times

211 more likely to have anxiety than NHCWs having household income $\geq$ PKR 120,000 PKR (aOR:

212 2.22, 95\% CI: 1.42-3.48, p-value: <0.001). NHCWs having COVID-19 related symptoms were 1.98

213 times more likely to have anxiety than HCWs without symptoms (aOR: 1.98; 95\% CI: 1.34-2.94, p-

214 value: 0.001$)$ (Refer to table 5).

215 Furthermore, presence of symptoms was positively associated with depression among HCWs (aOR:

216 2.72; 95\% CI: 1.34-5.55, p-value: 0.006). Household income had a positive association with

217 depression among NHCWs. NHCWs having income level of 60,001-120,000 PKR were nearly two

218 times more likely to have depression than NHCWs having household income > PKR 120,000 PKR

219 (aOR: 2.29, 95\% CI: 1.48-3.54, p-value: <0.001) (Refer to table 5). 
medRxiv preprint doi: https://doi.org/10.1101/2020.10.23.20218297; this version posted October 27, 2020. The copyright holder for this preprint (which was not certified by peer review) is the author/funder, who has granted medRxiv a license to display the preprint in perpetuity.

It is made available under a CC-BY-NC-ND 4.0 International license .

\section{Adoption of Precautionary Measures}

221 Significantly more HCWs reported wearing face masks (94\% HCWs vs. 91\% NHCWs, p-value

222 0.012), avoiding visiting meat shops or markets (77\% HCWs vs. 66\% NHCWs, p-value <0.001) than

223 NHCWs. Moreover, significantly less HCWs reported that they refrain from going to hospitals or

224 clinics $(60 \%$ HCWs vs. 81\% NHCWs, p-value <0.001) and work (55\% HCWs vs. 66\% NHCWs, p-

225 value<0.001) compared to NHCWs. Additionally, there was a statistically significant difference

226 between healthcare students' and graduates' adoption of some precautionary measures such as

227 washing their hands with soap/sanitizer frequently (96\% students vs. 99\% graduates, p-value 0.001),

228 avoiding going out (87\% students vs. 73\% graduates, p-value 0.003), refraining from going to

229 hospital or clinic $(80 \%$ students vs. $50 \%$ graduates, p-value <0.001) Similarly, a statistically

230 significant difference was noted between frontline and back-end HCWs in the adoption of some

231 precautionary measures such as washing their hands with soap/sanitizer frequently (100\% frontline

232 vs. $97 \%$ back-end, p-value 0.009, refraining from going to hospital or clinic (45\% frontline vs. $72 \%$

233 back-end, p-value<0.001) and avoiding going to work (37\% frontline vs. 68\% back-end, p-

234 value<0.00)1 (Refer to Table 6).

\section{Sources of Information utilized by the Respondents}

236 Nearly all HCWs and NHCWs remained alert to the disease progression of COVID-19 (96\% for the

237 former and $95 \%$ of the latter). The most trusted sources of information were doctors (91\% HCWs and

$23887 \%$ NHCWs, p-value 0.003) and government websites (85\% HCWs and 80\% NHCWs, p-value

239 0.056). Furthermore, significantly more NHCWs considered magazine (39\% HCWs vs. $44 \%$

240 NHCWs, p value 0.005), television (54\% HCWs vs. 63\% NHCWs, p value 0.043), family or friends

241 (46\% HCWs vs. 54\% NHCWs, p value 0.001) as reliable sources of information. Likewise, a

242 statistically significant percentage of healthcare students considered official government websites 
medRxiv preprint doi: https://doi.org/10.1101/2020.10.23.20218297; this version posted October 27, 2020. The copyright holder for this preprint (which was not certified by peer review) is the author/funder, who has granted medRxiv a license to display the preprint in perpetuity.

It is made available under a CC-BY-NC-ND 4.0 International license .

243 (86\% students vs. 84\% graduates), television (60\% students vs. 51\% graduates, p-value 0.040), radio

244 (58\% students vs. 44\% graduates, p-value; 0.017), and magazine (50\% students vs. 33\% graduates, p-

245 value; 0.015$)$ as reliable sources of information compared to healthcare graduates. Moreover,

246 compared to back-end HCWs, more frontline HCWs believed in the reliability of information

247 received through television (47\% frontline vs. 59\% back-end, p-value 0.049), radio (42\% frontline

248 vs. 54\% back-end, p-value 0.046), newspaper (49\% frontline vs. 62\% back-end, p-value 0.015), and

249 magazine (28\% frontline vs. 47\% back-end, p-value 0.015) (Refer to Table 7).

\section{Satisfaction with Government Measures}

251 Less than a third of HCWs and NHCWs were satisfied with the government's measures to control

252 COVID-19. HCWs, in comparison with NHCWs, were significantly more dissatisfied with the 253 availability of Personal Protective Equipment (62\% vs. 46\%, p value <0.001), testing kits (49\% vs. $25441 \%$, p value 0.028 ), and screening facilities ( $54 \%$ vs. $42 \%$, p value $<0.001$ ). Similarly, compared to 255 healthcare students, graduates were significantly more dissatisfied with screening facilities $(57 \%$ 256 graduates vs. $49 \%$ students, p-value0.016), testing kits (52\% graduates vs. $43 \%$ students, p-value 257 0.016), and quarantine facilities (49\% graduates vs. 38\% students, p-value 0.012). However, no 258 significant difference was seen between frontline and back-end HCWs' satisfaction with 259 government's measures to control COVID-19 (Refer to Table 8).

\section{Discussion}

261 The COVID-19 pandemic has caused a global health crisis. As the disease burden exponentially 262 increases, HCWs find themselves susceptible to contracting the disease or being the source of 263 exposure for their family members. This constant threat puts them at a high risk of psychological 264 distress. This study explores the similarities and differences in risk perceptions, anxiety levels, and 265 behavioral responses of HCWs and NHCWs in Pakistan during the COVID-19 pandemic. 
medRxiv preprint doi: https://doi.org/10.1101/2020.10.23.20218297; this version posted October 27, 2020. The copyright holder for this preprint (which was not certified by peer review) is the author/funder, who has granted medRxiv a license to display the preprint in perpetuity.

It is made available under a CC-BY-NC-ND 4.0 International license.

Respondents' adoption of precautionary measures and satisfaction with the government's response were also assessed.

This study showed that the perceived susceptibility and severity towards COVID-19 was high in both HCWs and NHCWs. Healthcare graduates perceived themselves and their families to be more susceptible to COVID-19 and found the disease to be much more severe than healthcare students. A study from Hong Kong showed an even higher perception of susceptibility and severity towards COVID-19 $(15,16)$. The generally high-risk perception levels can be explained by the coverage of the pandemic on social media as well as television sensitizing the people to the disease. Frequency of watching the media and sources of information has been known to influence risk perception (17). This is supported by reports from the MERS, SARS and H1N1 outbreaks $(18,19)$.

Additionally, frontline HCWs perceived themselves and their families to be more susceptible to COVID-19 than back-end HCWs while the latter perceived the disease to be more severe. Similar to HCWs in this study, training status and clinical placement creates differences in risk perception, as seen in the medical students of Iran (20). This indicates that HCWs felt more vulnerable with greater exposure to the infected individuals. Direct contact with COVID-19 patients is hence a major cause for concern among HCWs for themselves and their families. Greater perceived severity among backend workers on the other hand may be explained by the fact that since these workers are not seeing patients recover as frequently, their notion of disease severity is higher.

More than half the respondents in the study had some form of psychological distress (anxiety or depression). Data describing gaps in anxiety levels between HCWs and NHCWs is limited. Contrary to this study, which showed that both HCWs and NHCWs had similar high anxiety levels, HCWs in

287 Italy reported higher anxiety levels in comparison to the general population (21). Therefore, the gap 288 in anxiety levels seen in Italy (between HCWs and general population) is not seen in Pakistan. This 
medRxiv preprint doi: https://doi.org/10.1101/2020.10.23.20218297; this version posted October 27, 2020. The copyright holder for this preprint (which was not certified by peer review) is the author/funder, who has granted medRxiv a license to display the preprint in perpetuity.

It is made available under a CC-BY-NC-ND 4.0 International license .

Pakistan reported a lower disease burden compared to Italy, therefore it is possible that the HCWs in

Pakistan are generally less anxious due to a lesser case load and severity at the time of data

collection. A possible reason for higher anxiety levels in the NHCWs group in this study could be

292 due to higher sensitization by the social media creating undue anxiety. Another possible reason for

293 higher anxiety levels in the NHCWs group in this study could be a higher average education level

294 (Bachelor's) which is an independent risk factor for elevated anxiety symptoms (22).

Both HCWs and NHCWs had similar perceptions of the impact of COVID-19 on their daily routine.

The perceived impact, however, was greater among frontline HCWs compared to the back-end

HCWs. Frontline HCWs (doctors and nurses) are involved in more direct patient care and have

greater patient interaction. New protocols and added personal protective equipment (PPE) are

focused on frontline workers more which warrants a greater transition from the pre-pandemic life.

While backend HCWs (pharmacists, dentists, physiotherapists, allied health sciences, and students)

also had additions in their daily routine such as masks, social distancing, and hand sanitizing, these

changes are comparatively less cumbersome compared to changes in frontline HCW's routines. The

greater the patient interaction, greater number of precautions are required in daily routine which

results in greater impact on personal lives. A study reported nurses having more anxiety in

comparison to doctors as they are involved for a longer duration with the patients (23). Additionally,

frontline HCWs perceived themselves and their families to be more susceptible to COVID-19 than

back-end HCWs while the latter perceived the disease to be more severe. Greater perceived severity

among backend workers on the other hand may be explained by the fact that since these workers are not seeing patients recover as frequently, their notion of disease severity is higher.

310 This study pointed out that healthcare students were more depressed than the graduates. Existing data

311 that has generally shown students as a high risk group for depression (24). Experiences from the past 
medRxiv preprint doi: https://doi.org/10.1101/2020.10.23.20218297; this version posted October 27, 2020. The copyright holder for this preprint (which was not certified by peer review) is the author/funder, who has granted medRxiv a license to display the preprint in perpetuity.

It is made available under a CC-BY-NC-ND 4.0 International license.

312 epidemics also provide similar evidence (25-27). All educational institutes in Pakistan were closed

313 during the duration of the study. Although educational institutes adapted to online classes and virtual

314 examinations, it took a long while before students could get used to new routines and methods. These

315 interruptions in schedules, lack of physical interaction with peers and social isolation may have

316 contributed to the greater depression levels. Furthermore, students are often more active on social

317 media which has been a great source of information and sensitization of COVID-19 pandemic.

318 Constant ill news and disturbing figures may have further added to the current depression levels of

319 healthcare students. Healthcare students are required to rotate in pre-scheduled clinical clerkships

320 which mandates interactive patient care. Completing clinical clerkships require patient interaction

321 and are practically impossible in an online virtual setting which have led to delayed graduations. This

322 uncertainty and implications for a wasted academic year may also contribute to the increased

323 depression levels in healthcare students.

324 Female gender, younger age, and presence of COVID-19 related symptoms predicted increased

325 psychological distress in HCWs while lower-income and presence of COVID-19 related symptoms

326 predicted the same in NHCWs. Female gender has also been linked with greater anxiety levels in Iran

327 and China (24). Unlike our results, age did not predict psychological distress in the Chinese

328 population. The differences in the predictors of distress during the COVID-19 pandemic could be

329 attributed to the differences in countries' healthcare systems, the availability of personal protective

330 equipment (PPE), cultures, employment conditions, lockdown and work from home policies,

331 maintaining a living in a pandemic and mainstream and social media information, to name just a few.

332 COVID-19 has also increased the financial burden on households as many people struggle to run

333 small businesses and maintain daily income. The fear of not being able to fulfil the basic necessities

334 may be the reason why lower income can increase anxiety levels. The results, therefore, suggest the 
medRxiv preprint doi: https://doi.org/10.1101/2020.10.23.20218297; this version posted October 27, 2020. The copyright holder for this preprint (which was not certified by peer review) is the author/funder, who has granted medRxiv a license to display the preprint in perpetuity.

It is made available under a CC-BY-NC-ND 4.0 International license.

need for the identification of useful predictors of mental health in individual countries during the COVID-19 pandemic.

337 Only less than a third of HCWs and NHCWs were satisfied with the government's measures to

the availability of PPEs and screening facilities. Pakistan is a resource-limited country with no prior experience of handling a pandemic which may explain the lack of satisfaction with the government's response. This is concerning because healthcare staff's access to PPEs predicts lower distress levels, better physical health conditions, and more job satisfaction (28). Moreover, frontline HCWs who reuse or have inadequate access to PPE are known to have the higher risk of COVID-19 infection (29). Therefore, it is important for the government to address the concerns particularly among HCWs as they are the foot soldiers fighting the pandemic.

346 The main strength of this study is the comparison of various sub-groups within HCWs for a comprehensive analysis. In this respect, it is a novel study accounting for differences in experiences among HCWs. However, frontline and back-end categorization was made without using any standard classification. Moreover, in this study, most of the respondents were aged less than 35 years, which may not accurately represent the older population who are at greater risk for contracting COVID-19.

351 Nevertheless, as the majority of the population in Pakistan is below the age of 30 years, respondents are likely to represent the perceptions of the literate people. Lastly, this was an online survey with most respondents either having a Bachelor's degree or above. This may result in inadequately justifying the attitudes and perceptions of the NHCWs as the Pakistani population on average has a much lower educational background.

356 To decrease the level of psychological distress, hospital administrators should implement policies to 
medRxiv preprint doi: https://doi.org/10.1101/2020.10.23.20218297; this version posted October 27, 2020. The copyright holder for this preprint (which was not certified by peer review) is the author/funder, who has granted medRxiv a license to display the preprint in perpetuity.

It is made available under a CC-BY-NC-ND 4.0 International license .

monitored on a regular basis to avoid burnout. Incentives such as financial bonuses and paid leaves

should be provided. To cater for the individual needs of the population, communities should establish

online mental health and wellness groups to overcome social isolation. Government should ensure

361 provision of PPE, testing kits, and screening facilities to increase satisfaction levels of HCWs in

362 particular and the public at large. Furthermore, implementing these strategies may also contribute in

363 mitigating the disease spread. The better the disease is controlled, the lesser will be the psychological

364 morbidity and adverse impact on people's lives.

\section{Conclusion}

366 HCWs and NHCWs both have high levels of perceived susceptibility and severity along with

367 increased psychological distress. This study also identified vulnerable groups such as frontline

368 HCWs, healthcare students, younger aged people, females, and individuals with lower income to be

369 at a higher risk of psychological distress. We recommend exploring other vulnerable groups not

370 evaluated in this study such as COVID-19 positive patients, older and immunocompromised patients

371 for risk perceptions and psychological distress. Further studies need to investigate a direct link

372 between HCWs and the development of COVID-19 infection to quantify the infection risk. HCWs

373 are the frontline fighters against pandemics and preventing their psychological morbidity must be

374 prioritized for ensuring their well-being as well as that of patients that they treat within the health

375 care system.

376 Conflict of Interest

377 The authors declare that the research was conducted in the absence of any commercial or financial

378 relationships that could be construed as a potential conflict of interest.

\section{Author Contributions}


medRxiv preprint doi: https://doi.org/10.1101/2020.10.23.20218297; this version posted October 27, 2020. The copyright holder for this preprint (which was not certified by peer review) is the author/funder, who has granted medRxiv a license to display the preprint in perpetuity.

It is made available under a CC-BY-NC-ND 4.0 International license .

FR conceived the study, guided data collection and reviewed all drafts of the manuscript. AA and HS

381 adapted the questionnaires and wrote the manuscript. SP analyzed and narrated the data. HAK and

382 ARK edited and revised multiple drafts of the manuscript. ARK also assisted in adapting the

383 questionnaires and posting it on social media channels of AKU. All authors reviewed and endorsed

384 the final submission.

385 Funding

386 The authors did not receive any direct funding for the purpose of this study.

\section{Acknowledgments}

388 The authors would like to thank all the respondents of the survey from across Pakistan.

389 References

390 1. Lu H, Stratton CW, Tang Y-W. Outbreak of pneumonia of unknown etiology in Wuhan, China:

391 The mystery and the miracle. Journal of Medical Virology. 2020;92(4):401-2.

392 2. WHO. Rolling updates on coronavirus disease (COVID-19) [Internet]. World Health Organization. 2020 [cited 2020 May 29]. Available from:

394 https://www.who.int/emergencies/diseases/novel-coronavirus-2019/events-as-they-happen

395 3. COVID-19 Health Advisory Platform by Ministry of National Health Services Regulations and 396 Coordination [Internet]. [cited 2020 Jul 26]. Available from: http://covid.gov.pk/

397 4. Gallup Pakistan. Economic Impact of COVID-19 Lockdown on Pakistani Households. 398 Coronavirus Attitude Tracker Survey Pakistan. [Internet]. 2020 Apr [cited 2020 Jun 2]. Available 399 from: https://gallup.com.pk/economic-impact-of-covid-19-lockdown-on-pakistani-households/ 
medRxiv preprint doi: https://doi.org/10.1101/2020.10.23.20218297; this version posted October 27, 2020. The copyright holder for this preprint (which was not certified by peer review) is the author/funder, who has granted medRxiv a license to display the preprint in perpetuity.

It is made available under a CC-BY-NC-ND 4.0 International license .

400 5. Balicer RD, Omer SB, Barnett DJ, Everly GS. Local public health workers' perceptions toward 401 responding to an influenza pandemic. BMC Public Health. 2006;6(1):99.

402

6. Huang Y, Zhao N. Generalized anxiety disorder, depressive symptoms and sleep quality during

403 COVID-19 outbreak in China: a web-based cross-sectional survey. Psychiatry Research. 2020

404 Jun 1;288:112954.

7. Rajkumar RP. COVID-19 and mental health: A review of the existing literature. Asian Journal of Psychiatry. 2020 Aug 1;52:102066.

8. Lai J, Ma S, Wang Y, Cai Z, Hu J, Wei N, et al. Factors associated with mental health outcomes among health care workers exposed to coronavirus disease 2019. JAMA network open. 2020;3(3):e203976-e203976.

9. Aoyagi Y, Beck CR, Dingwall R, Nguyen-Van-Tam JS. Healthcare workers' willingness to work during an influenza pandemic: a systematic review and meta-analysis. Influenza and other respiratory viruses. 2015;9(3):120-130.

10. Tan BYQ, Chew NWS, Lee GKH, Jing M, Goh Y, Yeo LLL, et al. Psychological Impact of the 414 COVID-19 Pandemic on Health Care Workers in Singapore. Annals of Internal Medicine [Internet]. 2020 Apr 6; Available from: https://www.acpjournals.org/doi/full/10.7326/M20-1083 tertiary infectious disease hospital for COVID-19. Chinese journal of industrial hygiene and occupational diseases. 2020;38:E001-E001. 
medRxiv preprint doi: https://doi.org/10.1101/2020.10.23.20218297; this version posted October 27, 2020. The copyright holder for this preprint (which was not certified by peer review) is the author/funder, who has granted medRxiv a license to display the preprint in perpetuity. It is made available under a CC-BY-NC-ND 4.0 International license.

12. Wu P, Fang Y, Guan Z, Fan B, Kong J, Yao Z, et al. The psychological impact of the SARS epidemic on hospital employees in China: exposure, risk perception, and altruistic acceptance of risk. The Canadian Journal of Psychiatry. 2009;54(5):302-311.

13. Harvey A. Covid-19: medical students and FY1 doctors to be given early registration to help combat covid-19. BMJ. 2020 Mar 27;368:m1268.

14. Ives J, Greenfield S, Parry JM, Draper H, Gratus C, Petts JI, et al. Healthcare workers' attitudes to working during pandemic influenza: a qualitative study. BMC Public Health. 2009;9(1):56.

15. Kwok KO, Li KK, Chan HH, Yi YY, Tang A, Wei WI, et al. Community responses during the early phase of the COVID-19 epidemic in Hong Kong: risk perception, information exposure and preventive measures. Emerging Infectious Diseases [Internet]. 2020;26(7). Available from: https://wwwnc.cdc.gov/eid/article/26/7/20-0500_article

16. Kwok KO, Li KK, Chan HH, Yi YY, Tang A, Wei WI, et al. Community responses during the early phase of the COVID-19 epidemic in Hong Kong: risk perception, information exposure and preventive measures. medRxiv [Internet]. 2020; Available from: https://www.medrxiv.org/content/10.1101/2020.02.26.20028217v1.full.pdf

17. Karasneh R, Al-Azzam S, Muflih S, Soudah O, Hawamdeh S, Khader Y. Media's effect on shaping knowledge, awareness risk perceptions and communication practices of pandemic COVID-19 among pharmacists. Res Social Adm Pharm [Internet]. 2020 Apr 23 [cited 2020 Jul 25]; Available from: https://www.ncbi.nlm.nih.gov/pmc/articles/PMC7179508/

18. Choi D-H, Yoo W, Noh G-Y, Park K. The impact of social media on risk perceptions during the MERS outbreak in South Korea. Computers in Human Behavior. 2017 Jul;72:422-431. 
medRxiv preprint doi: https://doi.org/10.1101/2020.10.23.20218297; this version posted October 27, 2020. The copyright holder for this preprint (which was not certified by peer review) is the author/funder, who has granted medRxiv a license to display the preprint in perpetuity. It is made available under a CC-BY-NC-ND 4.0 International license .

440 19. Chang C. News coverage of health-related issues and its impacts on perceptions: Taiwan as an

$441 \quad$ example. Health communication. 2012;27(2):111-123.

442 20. Taghrir MH, Borazjani R, Shiraly R. COVID-19 and Iranian Medical Students; A Survey on 443 Their Related-Knowledge, Preventive Behaviors and Risk Perception. Arch Iran Med. 2020 Apr $444 \quad 1 ; 23(4): 249-54$.

445 21. Simione L, Gnagnarella C. Differences between health workers and general population in risk 446 perception, behaviors, and psychological distress related to COVID-19 spread in Italy. PsyArXiv 447 [Internet]. 2020 Apr; Available from: https://psyarxiv.com/84d2c

22. Du J, Dong L, Wang T, Yuan C, Fu R, Zhang L, et al. Psychological symptoms among frontline healthcare workers during COVID-19 outbreak in Wuhan. General Hospital Psychiatry [Internet]. 2020 Apr 3; $\quad$ Available from: http://www.sciencedirect.com/science/article/pii/S0163834320300451

24. Jahanshahi AA, Dinani MM, Madavani AN, Li J, Zhang SX. The distress of Iranian adults during the Covid-19 pandemic - More distressed than the Chinese and with different predictors. Brain, Behavior, and Immunity. 2020 Jul;87:124-5. Hong Kong. Stress and Health. 2007;23(1):31-5. 
medRxiv preprint doi: https://doi.org/10.1101/2020.10.23.20218297; this version posted October 27, 2020. The copyright holder for this preprint (which was not certified by peer review) is the author/funder, who has granted medRxiv a license to display the preprint in perpetuity. It is made available under a CC-BY-NC-ND 4.0 International license .

461 26. Coughlin SS. Anxiety and Depression: Linkages with Viral Diseases. Public Health Reviews. 2012 Dec;34(2):1-17.

27. Gawrilow C, Gollwitzer PM. Implementation Intentions Facilitate Response Inhibition in 464 Children with ADHD. Cognitive Therapy and Research. 2008 Apr 1;32(2):261-80. storm: Healthcare staff's health conditions and job satisfaction and their associated predictors during the epidemic peak of COVID-19. Brain, Behavior, and Immunity. 2020 Jul 1;87:144-6. frontline healthcare workers and the general community: a prospective cohort study. medRxiv [Internet] 2020 May $25 \quad[$ cited 2020 Jul 25]; Available from: https://www.medrxiv.org/content/10.1101/2020.04.29.20084111v6.full.pdf 
medRxiv preprint doi: https://doi.org/10.1101/2020.10.23.20218297; this version posted October 27, 2020. The copyright holder for this preprint (which was not certified by peer review) is the author/funder, who has granted medRxiv a license to display the preprint in perpetuity.

\section{It is made available under a CC-BY-NC-ND 4.0 International license .}

484

485

486

487 
medRxiv preprint doi: https://doi.org/10.1101/2020.10.23.20218297; this version posted October 27, 2020. The copyright holder for this preprint (which was not certified by peer review) is the author/funder, who has granted medRxiv a license to display the preprint in perpetuity.

It is made available under a CC-BY-NC-ND 4.0 International license .

Table 1. Socio-demographic Characteristics of the Respondents

\begin{tabular}{|c|c|c|}
\hline Characteristics & $\begin{array}{c}\text { HCWs } \\
\mathbf{n}=\mathbf{5 0 7} \\
\quad \text { No. }(\%)\end{array}$ & $\begin{array}{c}\text { NHCWs } \\
n=899\end{array}$ \\
\hline \multicolumn{3}{|l|}{ Gender } \\
\hline Male & $269(53.1)$ & $644(71.7)$ \\
\hline Female & $235(46.3)$ & $243(27.0)$ \\
\hline Prefer not to disclose & $3(0.6)$ & $12(1.3)$ \\
\hline \multicolumn{3}{|l|}{ Age } \\
\hline 18-24years & $220(43.4)$ & $239(26.6)$ \\
\hline $25-34$ years & $173(34.1)$ & $309(34.4)$ \\
\hline $35-44$ years & $69(13.6)$ & $213(23.7)$ \\
\hline 45-54years & $31(6.1)$ & $73(8.1)$ \\
\hline 55 or above & $14(2.8)$ & $61(6.8)$ \\
\hline Prefer not to disclose & 0 & $4(0.4)$ \\
\hline \multicolumn{3}{|l|}{ Education } \\
\hline Up to Matric/O-Levels & & $18(2.0)$ \\
\hline Intermediate/A-Levels/International Baccalaureate & & $110(12.2)$ \\
\hline Post-intermediate: Diploma/Certificate & & $22(2.5)$ \\
\hline Bachelor or above & & $743(82.6)$ \\
\hline Prefer not to disclose & & $6(0.7)$ \\
\hline \multicolumn{3}{|l|}{ Household incomes } \\
\hline PKR 40,000 or below & $73(22.4)$ & $246(27.4)$ \\
\hline PKR 40,001 - PKR 80,000 & $70(21.4)$ & $176(19.6)$ \\
\hline PKR 80,001 - PKR 120,000 & $50(15.4)$ & $156(17.3)$ \\
\hline$\geq$ PKR 120,001 & $56(17.2)$ & $142(15.8)$ \\
\hline Prefer not to disclose & $77(23.6)$ & $179(19.9)$ \\
\hline \multicolumn{3}{|l|}{ Permanent residence } \\
\hline a. Karachi & 249 (49.1) & $451(50.2)$ \\
\hline b. Lahore & $46(9.0)$ & $82(9.0)$ \\
\hline c. Islamabad & $24(4.8)$ & $61(6.8)$ \\
\hline d. Peshawar & $30(5.9)$ & $23(2.6)$ \\
\hline e. Quetta & $8(1.6)$ & $7(0.8)$ \\
\hline f. Hyderabad & $21(4.2)$ & $32(3.6)$ \\
\hline g. Others & $129(25.4)$ & $243(27.0)$ \\
\hline
\end{tabular}


medRxiv preprint doi: https://doi.org/10.1101/2020.10.23.20218297; this version posted October 27, 2020. The copyright holder for this preprint (which was not certified by peer review) is the author/funder, who has granted medRxiv a license to display the preprint in perpetuity.

It is made available under a CC-BY-NC-ND 4.0 International license .

490 Table 2. HCWs' field, training status, and current work status $(\mathbf{n}=\mathbf{5 0 7})$

Characteristics

Healthcare field

Medicine

Nursing

Pharmacy

Dentistry

$52(10.3)$

$42(8.3)$

$21(4.1)$

Physiotherapy

$24(4.7)$

Laboratory Technology or Allied Health Sciences

$87(17.2)$

Others

7 (1.4)

Training status

Student

$181(35.7)$

Graduate

$326(64.3)$

Current work status

Working in hospital/ ward/clinic

$117(35.9)$

Working from home (online/ telephone etc.)

49 (15.0)

Working in office setting

$28(8.6)$

Unpaid leave

$28(8.6)$

Paid leave

$18(5.5)$

Not working 
medRxiv preprint doi: https://doi.org/10.1101/2020.10.23.20218297; this version posted October 27, 2020. The copyright holder for this preprint (which was not certified by peer review) is the author/funder, who has granted medRxiv a license to display the preprint in perpetuity.

It is made available under a CC-BY-NC-ND 4.0 International license .

Table 3. Perceived severity and susceptibility for COVID-19

\begin{tabular}{|c|c|c|c|c|c|c|c|c|c|c|}
\hline Variable & Perception & $\begin{array}{l}\text { HCWs } \\
\text { n=507 } \\
\quad \text { No. }(\%)\end{array}$ & $\begin{array}{l}\text { NHCWs } \\
\begin{aligned} \text { n }=899 \\
\text { No. }(\%)\end{aligned}\end{array}$ & $\begin{array}{l}\text { HCWs } \\
\text { Vs } \\
\text { NHCW } \\
\text { s } \\
\text { P- } \\
\text { value* }\end{array}$ & $\begin{array}{l}\text { Health } \\
\text { care } \\
\text { Studen } \\
\text { ts } \\
\text { n= } 181 \\
\quad \text { No. } \\
\quad(\%) \\
\end{array}$ & $\begin{array}{l}\text { Healthcar } \\
\text { e } \\
\text { Graduate } \\
\text { s } \\
\mathbf{n}=\mathbf{3 2 6} \\
\quad \text { No. }(\%)\end{array}$ & $\begin{array}{l}\text { Studen } \\
\text { ts } \\
\text { Vs } \\
\text { Gradu } \\
\text { ates } \\
\text { P- } \\
\text { value* }\end{array}$ & $\begin{array}{l}\text { Frontli } \\
\text { ne } \\
\text { HCWs } \\
\text { n=216 } \\
\text { No. }(\%)\end{array}$ & $\begin{array}{l}\text { Backend } \\
\text { HCWs } \\
\text { n=290 } \\
\text { No. }(\%)\end{array}$ & $\begin{array}{l}\text { Frontli } \\
\text { ne Vs } \\
\text { Backen } \\
\text { d } \\
\text { P- } \\
\text { value* } \\
\end{array}$ \\
\hline \multicolumn{11}{|l|}{ Susceptibility } \\
\hline $\begin{array}{l}\text { 1. I might contract } \\
\text { the disease if no } \\
\text { preventive measure } \\
\text { is taken }\end{array}$ & $\begin{array}{l}\text { Agree } \\
\text { Neutral } \\
\text { Disagree } \\
\text { Don't know }\end{array}$ & $\begin{array}{r}382(75.3) \\
41(8.1) \\
81(16.0) \\
3(0.6) \\
\end{array}$ & $\begin{array}{r}636(70.7) \\
128(14.3) \\
129(14.3) \\
6(0.7) \\
\end{array}$ & 0.506 & $\begin{array}{r}120 \\
(66.3) \\
18(9.9) \\
42 \\
(23.2) \\
1(0.6) \\
\end{array}$ & $\begin{array}{r}262(80.4) \\
23(7.1) \\
39(11.9) \\
2(0.6) \\
\end{array}$ & 0.011 & $\begin{array}{r}179 \\
(82.9) \\
17(7.9) \\
20(9.2) \\
0 \\
\end{array}$ & $\begin{array}{r}203(69.8) \\
24(8.2) \\
61(21.0) \\
3(1.0) \\
\end{array}$ & 0.003 \\
\hline $\begin{array}{l}\text { 2. My family might } \\
\text { contract the disease } \\
\text { if no preventive } \\
\text { measure is taken }\end{array}$ & $\begin{array}{l}\text { Agree } \\
\text { Neutral } \\
\text { Disagree } \\
\text { Don't know }\end{array}$ & $\begin{array}{r}389(76.7) \\
31(6.1) \\
84(16.6) \\
3(0.6) \\
\end{array}$ & $\begin{array}{r}642(71.4) \\
116(12.9) \\
133(14.8) \\
8(0.9) \\
\end{array}$ & 0.539 & $\begin{array}{r}121 \\
(66.8) \\
15 \\
(18.3) \\
44 \\
(24.3) \\
1(0.6) \\
\end{array}$ & $\begin{array}{r}268(82.2) \\
16(4.9) \\
40(12.3) \\
2(0.6) \\
\end{array}$ & 0.008 & $\begin{array}{r}181 \\
(83.8) \\
10(4.6) \\
25 \\
(11.6) \\
0 \\
\end{array}$ & $\begin{array}{r}208(71.5) \\
21(7.2) \\
59(20.3) \\
3(1.0) \\
\end{array}$ & 0.006 \\
\hline $\begin{array}{l}\text { 3. I might contract } \\
\text { COVID-19 if one of } \\
\text { my family members } \\
\text { tests positive for the } \\
\text { disease }\end{array}$ & $\begin{array}{l}\text { Agree } \\
\text { Neutral } \\
\text { Disagree } \\
\text { Don't know }\end{array}$ & $\begin{array}{r}350(69.3) \\
60(11.9) \\
79(15.6) \\
16(3.2) \\
\end{array}$ & $\begin{array}{r}594(66.1) \\
140(15.5) \\
139(15.5) \\
26(2.9) \\
\end{array}$ & 0.559 & $\begin{array}{r}118 \\
(65.6) \\
18 \\
(10.0) \\
38 \\
(21.1) \\
6(3.3) \\
\end{array}$ & $\begin{array}{r}42(12.9) \\
41(12.6) \\
10(3.1) \\
\end{array}$ & 0.637 & $\begin{array}{r}158 \\
(73.5) \\
24 \\
(11.2) \\
27 \\
(12.5) \\
6(2.8) \\
\end{array}$ & $\begin{array}{r}36(12.4) \\
52(17.9) \\
10(3.4) \\
\end{array}$ & 0.138 \\
\hline Severity & & & & & & & & & & \\
\hline $\begin{array}{l}\text { 1. Seriousness of } \\
\text { symptoms caused by } \\
\text { SARS-CoV } 19\end{array}$ & $\begin{array}{l}\text { Severe } \\
\text { Neutral } \\
\text { Not Severe } \\
\text { Don't know }\end{array}$ & $\begin{array}{r}232(45.8) \\
148(29.2) \\
82(16.1) \\
45(8.9) \\
\end{array}$ & $\begin{array}{l}342(38.0) \\
192(21.4) \\
127(14.1) \\
238(26.5) \\
\end{array}$ & 0.916 & $\begin{array}{r}96 \\
(53.0) \\
45 \\
(24.9) \\
23 \\
(12.7) \\
17(9.4) \\
\end{array}$ & $\begin{array}{r}103(31.6) \\
59(18.1) \\
28(8.6) \\
\end{array}$ & 0.04 & $\begin{array}{r}93 \\
(43.1) \\
64 \\
(29.6) \\
44 \\
(20.4) \\
15(6.9) \\
\end{array}$ & $\begin{array}{c}139(47.9) \\
84(28.9) \\
38(13.0) \\
30(10.2) \\
\end{array}$ & 0.045 \\
\hline $\begin{array}{l}\text { 2. Chance of survival } \\
\text { if infected with } \\
\text { COVID-19 }\end{array}$ & $\begin{array}{l}\text { High } \\
\text { Neutral } \\
\text { Not high } \\
\text { Don't know }\end{array}$ & $\begin{array}{r}356(70.2) \\
105(20.7) \\
34(6.7) \\
12(2.4) \\
\end{array}$ & $\begin{array}{r}596(66.3) \\
173(19.2) \\
51(5.7) \\
79(8.8) \\
\end{array}$ & 0.807 & $\begin{array}{r}124 \\
(68.5) \\
40 \\
(20.1) \\
13(7.2) \\
4(2.2) \\
\end{array}$ & $\begin{array}{r}65(19.9) \\
21(6.4) \\
8(2.5) \\
\end{array}$ & 0.46 & $\begin{array}{r}147 \\
(68.1) \\
49 \\
(22.7) \\
17(7.9) \\
3(1.3) \\
\end{array}$ & $\begin{array}{r}56(19.3) \\
17(5.8) \\
9(3.1) \\
\end{array}$ & 0.188 \\
\hline
\end{tabular}

493 *Mann-Whitney test

494 Note: Categories were merged, so "agree/severe/high" and "strongly agree/ very severe/ very high" were merged into category

495 "agree/severe/high", and categories "disagree/ not severe/ not high" and "strongly disagree/ not severe at all/ not high at all" were

496 merged into "disagree/ not severe/ not high". 
medRxiv preprint doi: https://doi.org/10.1101/2020.10.23.20218297; this version posted October 27, 2020. The copyright holder for this preprint (which was not certified by peer review) is the author/funder, who has granted medRxiv a license to display the preprint in perpetuity. It is made available under a CC-BY-NC-ND 4.0 International license.

Table 4. Perceived Psychological Impact of COVID-19

\begin{tabular}{|c|c|c|c|c|c|c|c|c|c|c|}
\hline \multicolumn{2}{|l|}{ Variables } & $\begin{array}{l}\text { HCWs } \\
\text { n=507 } \\
\text { No. }(\%)\end{array}$ & $\begin{array}{l}\text { NHCWs } \\
\qquad \begin{array}{r}n=899 \\
\text { No. }(\%)\end{array}\end{array}$ & $\begin{array}{l}\text { HCW } \\
\text { s } \\
\text { Vs } \\
\text { NHC } \\
\text { Ws } \\
\text { P- } \\
\text { value }\end{array}$ & $\begin{array}{l}\text { HCW } \\
\text { Students } \\
\qquad \begin{array}{l}\text { n }=181 \\
\text { No. }(\%)\end{array}\end{array}$ & $\begin{array}{l}\text { HCW } \\
\text { Graduate } \\
\text { s } \\
\text { n }=326 \\
\text { No. }(\%)\end{array}$ & $\begin{array}{l}\text { Stude } \\
\text { nts } \\
\text { Vs } \\
\text { Grad } \\
\text { uates } \\
\text { P- } \\
\text { value }\end{array}$ & $\begin{array}{l}\text { Frontline } \\
\text { HCWs } \\
n=216 \\
\text { No. }(\%)\end{array}$ & $\begin{array}{l}\text { Backend } \\
\text { HCWs } \\
\text { n=290 } \\
\text { No. }(\%)\end{array}$ & $\begin{array}{l}\text { Frontl } \\
\text { ine Vs } \\
\text { Backe } \\
\text { nd } \\
\text { P- } \\
\text { value }\end{array}$ \\
\hline \multirow{3}{*}{$\begin{array}{l}\text { Anxiety (HADS-A } \\
\text { Score Cut-off } \geq 6 \text { ) }\end{array}$} & Normal & $235(46.4)$ & $407(45.3)$ & 0.697 & $78(43.1)$ & $157(48.2)$ & 0.273 & $96(44.4)$ & $139(47.8)$ & $0458 *$ \\
\hline & Abnormal & $272(53.6)$ & $492(54.7)$ & & $103(56.9)$ & $169(51.8)$ & & $120(55.6)$ & $152(52.2)$ & \\
\hline & $\begin{array}{l}\text { Mean } \\
\text { (SD) }\end{array}$ & $6.07(3.56)$ & $6.34(3.65)$ & $\begin{array}{r}0.177 \\
\dagger\end{array}$ & $\begin{array}{r}6.25 \\
(3.33)\end{array}$ & $\begin{array}{r}5.98 \\
(3.69)\end{array}$ & $\begin{array}{r}0.409 \\
+\end{array}$ & $6.9(3.60)$ & $\begin{array}{r}5.98 \\
(3.54)\end{array}$ & $0.509 \dagger$ \\
\hline \multirow{3}{*}{$\begin{array}{l}\text { Depression (HADS- } \\
\text { D Score Cut-off } \geq 8 \text { ) }\end{array}$} & Normal & $235(46.4)$ & $390(43.4)$ & 0.282 & 68 (37.6) & $167(51.2)$ & 0.003 & $109(50.5)$ & $126(43.3)$ & $0110 *$ \\
\hline & Abnormal & $272(53.6)$ & $509(56.6)$ & & $113(62.4)$ & $159(48.8)$ & & $107(49.5)$ & $165(56.7)$ & \\
\hline & $\begin{array}{l}\text { Mean } \\
\text { (SD) }\end{array}$ & 7.97 (3.69) & $8.26(3.83)$ & $\begin{array}{r}0.163 \\
\dagger\end{array}$ & $\begin{array}{r}8.40 \\
(3.45)\end{array}$ & $\begin{array}{r}7.72 \\
(3.80)\end{array}$ & $\begin{array}{r}\mathbf{0 . 0 4 7} \\
\dagger\end{array}$ & $\begin{array}{r}7.69 \\
(3.92)\end{array}$ & $\begin{array}{r}8.18 \\
(3.50)\end{array}$ & $0.139 \dagger$ \\
\hline \multirow{4}{*}{$\begin{array}{l}\text { COVID-19 will } \\
\text { affect my job }\end{array}$} & Agree & $315(62.3)$ & $529(58.8)$ & 0.592 & $105(58.3)$ & $210(64.4)$ & 0.844 & $146(67.6)$ & $169(58.4)$ & \\
\hline & Neutral & $65(12.8)$ & 167 (18.6) & $\ddagger$ & $28(15.6)$ & 37 (11.4) & $\neq$ & $26(12.0)$ & 39 (13.4) & $.250 \%$ \\
\hline & Disagree & $113(22.3)$ & 168 (18.7) & & 39 (21.7) & $74(22.7)$ & & $41(19.0)$ & $72(24.8)$ & \\
\hline & $\begin{array}{l}\text { Don't } \\
\text { know }\end{array}$ & $13(2.6)$ & 35 (3.9) & & $8(4.4)$ & $5(1.5)$ & & $3(1.4)$ & $10(3.4)$ & \\
\hline \multirow{4}{*}{$\begin{array}{l}\text { COVID-19 will } \\
\text { affect my personal } \\
\text { life }\end{array}$} & Agree & $331(65.3)$ & $561(62.4)$ & 0.877 & $112(61.9)$ & $219(67.2)$ & 0.260 & $161(74.5)$ & $170(58.4)$ & $<0.001$ \\
\hline & Neutral & $70(13.8)$ & $176(19.6)$ & $\neq$ & $26(14.4)$ & $44(13.5)$ & $\neq$ & $23(10.6)$ & $47(16.2)$ & $\ddagger$ \\
\hline & Disagree & $101(19.9)$ & 149 (16.6) & & $41(22.6)$ & $60(18.4)$ & & $31(14.4)$ & $70(24.1)$ & \\
\hline & $\begin{array}{l}\text { Don't } \\
\text { know }\end{array}$ & $5(1.0)$ & $13(1.4)$ & & $2(1.1)$ & $3(0.9)$ & & $1(0.5)$ & $4(1.3)$ & \\
\hline \multirow{4}{*}{$\begin{array}{l}\text { COVID-19 has } \\
\text { affected my sleeping } \\
\text { pattern }\end{array}$} & Agree & $175(34.5)$ & $374(41.6)$ & 0.060 & $63(34.8)$ & $112(34.4)$ & 0.324 & $79(36.6)$ & $96(33.0)$ & \\
\hline & Neutral & $90(17.8)$ & $150(16.7)$ & $\neq$ & $33(18.2)$ & $57(17.5)$ & $\ddagger$ & 33 (15.3) & 57 (19.6) & \\
\hline & Disagree & $220(43.4)$ & $351(39.0)$ & & 74 (40.9) & $146(44.8)$ & & $97(44.9)$ & $123(42.3)$ & \\
\hline & $\begin{array}{l}\text { Don't } \\
\text { know }\end{array}$ & $22(4.3)$ & $24(2.7)$ & & $11(6.1)$ & $11(3.3)$ & & $7(3.2)$ & $15(5.1)$ & \\
\hline \multirow{3}{*}{$\begin{array}{l}\text { COVID-19 has } \\
\text { affected my eating } \\
\text { habits }\end{array}$} & Agree & $167(33.0)$ & $335(37.3)$ & 0.108 & 68 (37.6) & 99 (30.5) & 0.100 & 69 (32.2) & 98 (33.7) & 0.302 \\
\hline & & $\begin{array}{r}88(17.4) \\
236(46.6)\end{array}$ & $\begin{array}{l}165(18.4) \\
378(42.0)\end{array}$ & & $\begin{array}{l}29(16.0) \\
77(42.5)\end{array}$ & $\begin{array}{r}59(18.2) \\
159(48.8)\end{array}$ & & $\begin{array}{r}36(16.7) \\
105(48.8)\end{array}$ & $\begin{array}{r}52(17.9) \\
131(45.0)\end{array}$ & \\
\hline & $\begin{array}{l}\text { Don't } \\
\text { know }\end{array}$ & $15(3.0)$ & $21(2.3)$ & & & $8(2.5)$ & & $5(2.3)$ & $10(3.4)$ & \\
\hline \multirow{4}{*}{$\begin{array}{l}\text { I might } \\
\text { start/increase } \\
\text { smoking cigarettes }\end{array}$} & Agree & $54(10.7)$ & $78(8.7)$ & 0.461 & $20(11.1)$ & $34(10.4)$ & 0675 & $27(12.5)$ & $27(9.3)$ & $0420 \%$ \\
\hline & Neutral & $32(6.3)$ & $89(9.9)$ & 丰 & $10(5.5)$ & $19(5.8)$ & $0.6 / 5$ & $13(6.0)$ & $19(6.5)$ & 0.4297 \\
\hline & Disagree & $397(78.3)$ & $692(77.0)$ & & 141 (77.9) & $256(78.5)$ & & $166(76.9)$ & $231(79.4)$ & \\
\hline & $\begin{array}{l}\text { Don't } \\
\text { know }\end{array}$ & $24(4.7)$ & $40(4.4)$ & & $10(5.5)$ & $14(4.3)$ & & $10(4.6)$ & $14(4.8)$ & \\
\hline \multirow{4}{*}{$\begin{array}{l}\text { I might } \\
\text { start/increase the } \\
\text { use of recreational } \\
\text { drugs }\end{array}$} & Agree & $34(6.7)$ & $38(4.2)$ & 0.154 & $11(6.1)$ & $23(7.1)$ & 0303 & $19(8.8)$ & $15(5.2)$ & \\
\hline & Neutral & $31(6.1)$ & $61(6.8)$ & † & $6(3.3)$ & 25 (7.6) & 0.393 & $12(5.6)$ & $19(6.5)$ & $0.30 / 7$ \\
\hline & Disagree & $419(82.6)$ & $757(84.2)$ & & $153(84.5)$ & $266(81.6)$ & & $177(81.9)$ & $242(83.1)$ & \\
\hline & $\begin{array}{l}\text { Don't } \\
\text { know }\end{array}$ & & $43(4.8)$ & & $11(6.1)$ & $12(3.7)$ & & $8(3.7)$ & $15(5.2)$ & \\
\hline
\end{tabular}

498 *Pearson Chi-square test †Independent-samples t-test $\$$ Mann-Whitney test

499 Note: Percentages of categories "agree/ strongly agree" were merged into category "agree”, and categories "disagree/ strongly

500 disagree" were merged into "disagree". 
medRxiv preprint doi: https://doi.org/10.1101/2020.10.23.20218297; this version posted October 27, 2020. The copyright holder for this preprint (which was not certified by peer review) is the author/funder, who has granted medRxiv a license to display the preprint in perpetuity.

It is made available under a CC-BY-NC-ND 4.0 International license.

$501 \quad$ Table 5. Predictors of Anxiety and Depression

\begin{tabular}{|c|c|c|c|c|c|c|c|c|}
\hline \multirow{3}{*}{ Variable } & \multicolumn{4}{|c|}{ Anxiety } & \multicolumn{4}{|c|}{ Depression } \\
\hline & \multicolumn{2}{|c|}{$\begin{array}{c}\text { HCWs } \\
(\mathbf{n}=507)\end{array}$} & \multicolumn{2}{|c|}{$\begin{array}{c}\text { NHCWs } \\
(\mathbf{n}=899)\end{array}$} & \multicolumn{2}{|c|}{ HCWs } & \multicolumn{2}{|c|}{ NHCWs } \\
\hline & $\begin{array}{l}\text { aOR } *(95 \% \\
\text { CI) }\end{array}$ & $\begin{array}{l}\text { P- } \\
\text { value }\end{array}$ & $\begin{array}{l}\text { aOR } *(95 \% \\
\text { CI) }\end{array}$ & $\begin{array}{l}\text { P- } \\
\text { value }\end{array}$ & $\begin{array}{l}\text { aOR* }(95 \% \\
\text { CI) }\end{array}$ & $\begin{array}{l}\text { P- } \\
\text { value }\end{array}$ & $\begin{array}{l}\text { aOR* }(95 \% \\
\text { CI) }\end{array}$ & $\begin{array}{l}\text { P- } \\
\text { value }\end{array}$ \\
\hline \multicolumn{9}{|l|}{ Gender } \\
\hline Female & $\begin{array}{l}2.34(1.37- \\
3.99)\end{array}$ & 0.002 & $\begin{array}{l}1.62(1.12- \\
2.35)\end{array}$ & 0.010 & $\begin{array}{l}1.53(0.90- \\
2.58)\end{array}$ & 0.115 & $\begin{array}{l}1.41(0.98- \\
2.02)\end{array}$ & 0.065 \\
\hline Male & Reference & & Reference & & Reference & & Reference & \\
\hline \multicolumn{9}{|l|}{ Age } \\
\hline 18-24years & $\begin{array}{l}3.52(1.19- \\
10.42)\end{array}$ & 0.023 & $\begin{array}{l}2.53(1.51- \\
4.23)\end{array}$ & $\begin{array}{l}<0.00 \\
1\end{array}$ & $\begin{array}{l}1.00(0.37- \\
2.71)\end{array}$ & 1.000 & $\begin{array}{l}1.38(0.84- \\
2.27)\end{array}$ & 0.209 \\
\hline $25-34$ years & $\begin{array}{l}3.44(1.30- \\
9.09)\end{array}$ & 0.013 & $\begin{array}{l}2.84(1.75- \\
4.62)\end{array}$ & $\begin{array}{l}<0.00 \\
1\end{array}$ & $\begin{array}{l}1.72(0.72- \\
4.11)\end{array}$ & 0.219 & $\begin{array}{l}1.26(0.79- \\
2.01)\end{array}$ & 0.325 \\
\hline $35-44$ years & $\begin{array}{l}4.68(1.63- \\
13.47)\end{array}$ & 0.004 & $\begin{array}{l}2.21(1.31- \\
3.70)\end{array}$ & 0.003 & $\begin{array}{l}1.01(0.39- \\
2.64)\end{array}$ & 0.978 & $\begin{array}{l}1.66(1.00- \\
2.76)\end{array}$ & 0.050 \\
\hline 45 years or above & Reference & & Reference & & Reference & & Reference & \\
\hline \multicolumn{9}{|l|}{ Household incomes } \\
\hline$\leq$ PKR 60,000 & $\begin{array}{l}1.30(0.62- \\
2.71)\end{array}$ & 0.491 & $\begin{array}{l}1.61(1.06- \\
2.43)\end{array}$ & 0.024 & $\begin{array}{l}1.12(0.54- \\
2.32)\end{array}$ & 0.762 & $\begin{array}{l}1.58(1.06- \\
2.36)\end{array}$ & 0.026 \\
\hline PKR 60,001 - PKR 120,000 & $\begin{array}{l}1.35(0.64- \\
2.84)\end{array}$ & 0.430 & $\begin{array}{l}2.22(1.42- \\
3.48)\end{array}$ & $\begin{array}{l}<0.00 \\
1\end{array}$ & $\begin{array}{l}1.25(0.61- \\
2.57)\end{array}$ & 0.548 & $\begin{array}{l}2.29(1.48- \\
3.54)\end{array}$ & $\begin{array}{l}<0.00 \\
1\end{array}$ \\
\hline > PKR 120,000 & Reference & & Reference & & Reference & & Reference & \\
\hline \multicolumn{9}{|l|}{$\begin{array}{l}\text { Presence of COVID-19 related } \\
\text { Symptoms }\end{array}$} \\
\hline Yes & $\begin{array}{l}2.09(1.01- \\
4.32)\end{array}$ & 0.046 & $\begin{array}{l}1.98(1.34- \\
2.94)\end{array}$ & 0.001 & $\begin{array}{l}2.72(1.34- \\
5.55)\end{array}$ & 0.006 & $\begin{array}{l}1.41(0.96- \\
2.06)\end{array}$ & 0.077 \\
\hline No & Reference & & Reference & & Reference & & Reference & \\
\hline
\end{tabular}

502 *Adjusted for gender, age, household income, and presence of COVID-19 related symptoms.

503 
medRxiv preprint doi: https://doi.org/10.1101/2020.10.23.20218297; this version posted October 27, 2020. The copyright holder for this preprint (which was not certified by peer review) is the author/funder, who has granted medRxiv a license to display the preprint in perpetuity.

It is made available under a CC-BY-NC-ND 4.0 International license.

504 Table 6. Adoption of Precautions by the respondents (Number of respondents answering Yes")

\begin{tabular}{|c|c|c|c|c|c|c|c|c|c|}
\hline Precautions & $\begin{array}{l}\text { HCWs } \\
\text { n=507 } \\
\text { No. }(\%)\end{array}$ & $\begin{array}{l}\text { NHCWs } \\
\text { n =899 } \\
\text { No. }(\%)\end{array}$ & $\begin{array}{l}\text { HCWs } \\
\text { Vs } \\
\text { NHCWs } \\
\text { P-value* }\end{array}$ & $\begin{array}{l}\text { Healthca } \\
\text { re } \\
\text { Students } \\
\mathbf{n}=181 \\
\text { No. }(\%)\end{array}$ & $\begin{array}{l}\text { Healthcar } \\
\text { e } \\
\text { Graduate } \\
\mathrm{s} \\
\mathrm{n}=\mathbf{3 2 6} \\
\text { No. }(\%)\end{array}$ & $\begin{array}{l}\text { Students } \\
\text { Vs } \\
\text { Graduat } \\
\text { es } \\
\text { P-value* }\end{array}$ & $\begin{array}{l}\text { Frontline } \\
\text { NHCWs } \\
\text { n=216 } \\
\text { No. }(\%)\end{array}$ & $\begin{array}{l}\text { Backend } \\
\text { NHCWs } \\
\text { n=290 } \\
\text { No. }(\%)\end{array}$ & $\begin{array}{l}\text { Frontlin } \\
\text { e } \\
\text { Vs } \\
\text { Backend } \\
\text { P-value* }\end{array}$ \\
\hline 1. Wear face masks & 475 (93.7) & 815 (90.7) & 0.012 & $\begin{array}{r}161 \\
(89.0)\end{array}$ & $314(96.3)$ & 0.082 & $208(96.3)$ & $\begin{array}{r}267 \\
(91.8)\end{array}$ & 0.344 \\
\hline $\begin{array}{l}\text { 2. Wash hands frequently } \\
\text { (With soap or hand } \\
\text { sanitizer) }\end{array}$ & 497 (98.0) & 884 (98.3) & 0.756 & $\begin{array}{r}173 \\
(95.6)\end{array}$ & $324(99.4)$ & 0.001 & $215(99.5)$ & $\begin{array}{r}282 \\
(96.9)\end{array}$ & 0.009 \\
\hline $\begin{array}{l}\text { 3. Avoid contacting people } \\
\text { who have fever or } \\
\text { respiratory symptoms }\end{array}$ & $470(92.7)$ & $825(91.8)$ & 0.597 & $\begin{array}{r}163 \\
(90.1)\end{array}$ & 307 (94.2) & 0.047 & $203(94.0)$ & $\begin{array}{r}267 \\
(91.8)\end{array}$ & 0.212 \\
\hline 4. Avoid going out & 397 (78.3) & $679(75.5)$ & 0.089 & $\begin{array}{r}158 \\
(87.3)\end{array}$ & $239(73.3)$ & 0.003 & $164(75.9)$ & $\begin{array}{r}233 \\
(80.1)\end{array}$ & 0.685 \\
\hline $\begin{array}{l}\text { 5. Avoid going to meat } \\
\text { shops/market }\end{array}$ & $391(77.1)$ & $592(65.9)$ & $<0.001$ & $\begin{array}{r}142 \\
(78.5)\end{array}$ & $249(76.4)$ & 0.291 & $172(79.6)$ & $\begin{array}{r}219 \\
(75.3)\end{array}$ & 0.330 \\
\hline $\begin{array}{l}\text { 6. Avoid going to hospital } \\
\text { or clinic }\end{array}$ & $306(60.4)$ & $728(81.0)$ & $<0.001$ & $\begin{array}{r}144 \\
(79.6)\end{array}$ & $162(49.7)$ & $<0.001$ & 97 (44.9) & $\begin{array}{r}209 \\
(71.8)\end{array}$ & $<0.001$ \\
\hline $\begin{array}{l}\text { 7. Avoid taking public } \\
\text { transportation }\end{array}$ & 456 (89.9) & $838(93.2)$ & $<0.021$ & $\begin{array}{r}165 \\
(91.2)\end{array}$ & $291(89.3)$ & 0.651 & $193(89.4)$ & $\begin{array}{r}263 \\
(90.4)\end{array}$ & 0.207 \\
\hline 8. Avoid going to work & 277 (54.6) & $594(66.1)$ & $<0.001$ & $\begin{array}{r}137 \\
(75.7)\end{array}$ & $140(42.9)$ & $<0.001$ & $80(37.0)$ & $\begin{array}{r}197 \\
(67.7)\end{array}$ & $<0.001$ \\
\hline $\begin{array}{l}\text { 9. Avoid going to school or } \\
\text { avoid letting children go } \\
\text { to school }\end{array}$ & $382(75.3)$ & $811(90.2)$ & 0.001 & $\begin{array}{r}154 \\
(85.1)\end{array}$ & $228(69.9)$ & 0.024 & $149(69.0)$ & $\begin{array}{r}233 \\
(80.1)\end{array}$ & 0.733 \\
\hline 10. Avoid international travel & $467(92.1)$ & $853(94.9)$ & 0.032 & $\begin{array}{r}169 \\
(93.4)\end{array}$ & $298(91.4)$ & 0.954 & $198(91.7)$ & $\begin{array}{r}269 \\
(92.4)\end{array}$ & 0.980 \\
\hline $\begin{array}{l}\text { 11. Avoid domestic or inter- } \\
\text { city travel }\end{array}$ & $440(86.8)$ & $805(89.5)$ & 0.076 & $\begin{array}{r}165 \\
(91.2)\end{array}$ & $275(84.4)$ & 0.091 & $174(80.6)$ & $\begin{array}{r}266 \\
(91.4)\end{array}$ & 0.001 \\
\hline
\end{tabular}

$505 *$ Pearson Chi-square test

506 Note: Only the most salient variables for social distancing have been reported in this table. 
medRxiv preprint doi: https://doi.org/10.1101/2020.10.23.20218297; this version posted October 27, 2020. The copyright holder for this preprint (which was not certified by peer review) is the author/funder, who has granted medRxiv a license to display the preprint in perpetuity.

It is made available under a CC-BY-NC-ND 4.0 International license.

507 Table 7. Perceived reliability of information sources

\begin{tabular}{|c|c|c|c|c|c|c|c|c|c|}
\hline $\begin{array}{l}\text { Information } \\
\text { Source }\end{array}$ & Perception & $\begin{array}{r}\text { HCWs } \\
\text { n=488 } \\
\text { No. }(\%)\end{array}$ & $\begin{array}{l}\text { NHCWs } \\
\begin{array}{r}\text { n }=864 \\
\text { No. }(\%)\end{array}\end{array}$ & $\begin{array}{l}\text { HCWs } \\
\text { Vs } \\
\text { NHCW } \\
\text { s } \\
\text { P- } \\
\text { value* }\end{array}$ & $\begin{array}{l}\text { Healthcar } \\
\text { e } \\
\text { Students } \\
\qquad \begin{array}{l}\text { n }=175 \\
\text { No. }(\%)\end{array}\end{array}$ & $\begin{array}{l}\text { Healthcar } \\
\text { e } \\
\text { Graduate } \\
\text { s } \\
\quad \mathbf{n}=\mathbf{3 1 3} \\
\text { No. }(\%)\end{array}$ & $\begin{array}{l}\text { Student } \\
\text { s } \\
\text { Vs } \\
\text { Gradua } \\
\text { tes } \\
\quad \text { P- } \\
\text { value* }\end{array}$ & $\begin{array}{l}\text { Frontline } \\
\text { HCWs } \\
\begin{array}{r}\text { n=206 } \\
\text { No. }(\%)\end{array}\end{array}$ & $\begin{array}{l}\text { Backend } \\
\text { HCWs } \\
\text { n=282 } \\
\text { No. }(\%)\end{array}$ \\
\hline Newspaper & $\begin{array}{l}\text { Reliable } \\
\text { Neutral } \\
\text { Unreliable }\end{array}$ & $\begin{array}{r}268(56.5) \\
138(29.2) \\
68(14.3)\end{array}$ & $\begin{array}{r}500(57.9) \\
273(31.7) \\
90(10.4)\end{array}$ & 0.239 & $\begin{array}{r}105(63.2) \\
36(21.7) \\
25(15.1)\end{array}$ & $\begin{array}{r}163(52.9) \\
102(33.1) \\
43(14.0)\end{array}$ & 0.071 & $\begin{array}{r}100(49.0) \\
77(37.8) \\
27(13.2)\end{array}$ & $\begin{array}{r}168(62.2) \\
61(22.6) \\
41(15.2)\end{array}$ \\
\hline Magazine & $\begin{array}{l}\text { Reliable } \\
\text { Neutral } \\
\text { Unreliable }\end{array}$ & $\begin{array}{l}189(39.0) \\
176(36.3) \\
120(24.7)\end{array}$ & $\begin{array}{l}378(43.7) \\
347(40.2) \\
139(16.1)\end{array}$ & 0.005 & $\begin{array}{l}87(50.3) \\
44(25.4) \\
42(24.3)\end{array}$ & $\begin{array}{r}102(32.7) \\
132(42.3) \\
78(25.0)\end{array}$ & 0.015 & $\begin{array}{l}58(28.3) \\
94(45.8) \\
53(25.9)\end{array}$ & $\begin{array}{r}131(46.8) \\
82(29.3) \\
67(23.9)\end{array}$ \\
\hline Radio & $\begin{array}{l}\text { Reliable } \\
\text { Neutral } \\
\text { Unreliable }\end{array}$ & $\begin{array}{r}238(49.0) \\
163(33.5) \\
85(17.5)\end{array}$ & $\begin{array}{r}463(53.6) \\
311(36.0) \\
90(10.4)\end{array}$ & 0.051 & $\begin{array}{r}100(57.5) \\
44(25.3) \\
30(17.2)\end{array}$ & $\begin{array}{r}138(44.2) \\
119(38.1) \\
55(17.6)\end{array}$ & 0.017 & $\begin{array}{l}86(42.0) \\
84(41.0) \\
35(17.0)\end{array}$ & $\begin{array}{r}152(54.1) \\
79(28.1) \\
50(17.8)\end{array}$ \\
\hline Television & $\begin{array}{l}\text { Reliable } \\
\text { Neutral } \\
\text { Unreliable }\end{array}$ & $\begin{array}{r}262(53.9) \\
141(29.0) \\
83(17.1)\end{array}$ & $\begin{array}{l}546(63.2) \\
186(21.5) \\
132(15.3)\end{array}$ & 0.043 & $\begin{array}{r}104(59.8) \\
43(24.7) \\
27(15.5)\end{array}$ & $\begin{array}{r}158(50.6) \\
98(31.4) \\
56(18.0)\end{array}$ & 0.040 & $\begin{array}{l}97(47.3) \\
73(35.6) \\
35(17.1)\end{array}$ & $\begin{array}{r}165(58.7) \\
68(24.2) \\
48(17.1)\end{array}$ \\
\hline $\begin{array}{l}\text { Government } \\
\text { websites }\end{array}$ & $\begin{array}{l}\text { Reliable } \\
\text { Neutral } \\
\text { Unreliable }\end{array}$ & $\begin{array}{r}411(84.6) \\
48(9.9) \\
27(5.5)\end{array}$ & $\begin{array}{r}693(80.2) \\
110(12.7) \\
61(7.1)\end{array}$ & 0.056 & $\begin{array}{r}150(86.2) \\
13(7.5) \\
11(6.3)\end{array}$ & $\begin{array}{r}261(83.7) \\
35(11.2) \\
16(5.1)\end{array}$ & 0.001 & $\begin{array}{r}168(81.9) \\
25(12.2) \\
12(5.9)\end{array}$ & $\begin{array}{r}243(86.5) \\
23(8.2) \\
15(5.3)\end{array}$ \\
\hline $\begin{array}{l}\text { Unofficial } \\
\text { websites }\end{array}$ & $\begin{array}{l}\text { Reliable } \\
\text { Neutral } \\
\text { Unreliable }\end{array}$ & $\begin{array}{l}134(27.7) \\
118(24.4) \\
232(47.9)\end{array}$ & $\begin{array}{l}237(27.4) \\
282(32.7) \\
345(39.9)\end{array}$ & 0.156 & $\begin{array}{l}59(33.9) \\
28(16.1) \\
87(50.0)\end{array}$ & $\begin{array}{r}75(24.2) \\
90(29.0) \\
145(46.8)\end{array}$ & 0.983 & $\begin{array}{r}41(20.2) \\
61(30.0) \\
101(49.8)\end{array}$ & $\begin{array}{r}93(33.1) \\
57(20.3) \\
131(46.6)\end{array}$ \\
\hline $\begin{array}{l}\text { Social media } \\
\text { platforms }\end{array}$ & $\begin{array}{l}\text { Reliable } \\
\text { Neutral } \\
\text { Unreliable }\end{array}$ & $\begin{array}{r}149(30.7) \\
96(19.7) \\
241(49.6)\end{array}$ & $\begin{array}{l}273 \text { (31.6) } \\
276(31.9) \\
315(36.5)\end{array}$ & 0.004 & $\begin{array}{l}65(37.1) \\
23(13.2) \\
87(49.7)\end{array}$ & $\begin{array}{r}84(27.0) \\
73(23.5) \\
154(49.5)\end{array}$ & 0.358 & $\begin{array}{r}50(24.5) \\
54(26.5) \\
100(49.0)\end{array}$ & $\begin{array}{r}99(35.1) \\
42(14.9) \\
141(50.0)\end{array}$ \\
\hline Doctor & $\begin{array}{l}\text { Reliable } \\
\text { Neutral } \\
\text { Unreliable }\end{array}$ & $\begin{array}{r}443(91.2) \\
35(7.2) \\
8(1.6)\end{array}$ & $\begin{array}{r}753(87.2) \\
97(11.2) \\
14(1.6)\end{array}$ & 0.003 & $\begin{array}{r}158(90.3) \\
12(6.9) \\
5(2.8)\end{array}$ & $\begin{array}{r}285(91.6) \\
23(7.4) \\
3(1.0)\end{array}$ & 0.942 & $\begin{array}{r}186(90.7) \\
16(7.8) \\
3(1.5)\end{array}$ & $\begin{array}{r}257(91.4) \\
19(6.8) \\
5(1.8)\end{array}$ \\
\hline $\begin{array}{l}\text { Family or } \\
\text { friends }\end{array}$ & $\begin{array}{l}\text { Reliable } \\
\text { Neutral } \\
\text { Unreliable }\end{array}$ & $\begin{array}{l}221(45.7) \\
158(32.6) \\
105(21.7)\end{array}$ & $\begin{array}{l}464(53.8) \\
290(33.6) \\
109(12.6)\end{array}$ & 0.001 & $\begin{array}{l}74(42.3) \\
57(32.6) \\
44(25.1)\end{array}$ & $\begin{array}{r}147(47.6) \\
101(32.7) \\
61(19.7)\end{array}$ & 0.185 & $\begin{array}{l}85(41.9) \\
71(34.9) \\
47(23.2)\end{array}$ & $\begin{array}{r}136(48.4) \\
87(31.0) \\
58(20.6)\end{array}$ \\
\hline
\end{tabular}

508 *Mann Whitney test

509 Note: Percentages of categories "reliable/ very reliable" were merged into category "reliable", and categories "unreliable / very

510 unreliable" were merged "unreliable”. 
medRxiv preprint doi: https://doi.org/10.1101/2020.10.23.20218297; this version posted October 27, 2020. The copyright holder for this preprint (which was not certified by peer review) is the author/funder, who has granted medRxiv a license to display the preprint in perpetuity.

It is made available under a CC-BY-NC-ND 4.0 International license .

Table 8. Respondents' satisfaction with government measures

\begin{tabular}{|c|c|c|c|c|c|c|c|c|c|}
\hline Measures & $\begin{array}{l}\text { HCWs } \\
\text { n=507 } \\
\text { No. }(\%)\end{array}$ & $\begin{array}{l}\text { NHCWs } \\
\text { n =589 } \\
\text { No. }(\%)\end{array}$ & $\begin{array}{l}\text { HCWs } \\
\text { Vs } \\
\text { NHCW } \\
\text { s } \\
\text { P- } \\
\text { value* }\end{array}$ & $\begin{array}{l}\text { Healthcar } \\
\text { e } \\
\text { Students } \\
\text { n= } 181 \\
\text { No. }(\%)\end{array}$ & $\begin{array}{l}\text { Healthca } \\
\text { re } \\
\text { Graduate } \\
\mathrm{s} \\
\mathrm{n}=\mathbf{3 2 6} \\
\text { No. }(\%)\end{array}$ & $\begin{array}{l}\text { Student } \\
\text { s } \\
\text { Vs } \\
\text { Gradua } \\
\text { tes } \\
\text { P- } \\
\text { value* }\end{array}$ & $\begin{array}{l}\text { Frontline } \\
\text { NHCWs } \\
\text { n=216 } \\
\text { No. }(\%)\end{array}$ & $\begin{array}{l}\text { Backend } \\
\text { NHCWs } \\
\text { n=290 } \\
\text { No. }(\%)\end{array}$ & $\begin{array}{l}\text { Frontli } \\
\text { ne } \\
\text { Vs } \\
\text { Backen } \\
\text { d } \\
\text { P- } \\
\text { value* }\end{array}$ \\
\hline \multicolumn{10}{|l|}{ Screening facilities } \\
\hline Satisfied/ Very Satisfied & $104(20.6)$ & $111(18.8)$ & $<0.001$ & $46(25.6)$ & $58(17.9)$ & 0.016 & $39(18.2)$ & $65(22.4)$ & 0.245 \\
\hline Neutral & $117(23.2)$ & $198(33.6)$ & & $44(24.4)$ & $73(22.5)$ & & $49(23.0)$ & $68(23.4)$ & \\
\hline Unsatisfied/ Very Unsatisfied & $273(54.2)$ & $248(42.2)$ & & $89(49.4)$ & $184(56.8)$ & & $124(57.9)$ & $149(51.4)$ & \\
\hline Don’t know & $10(2.0)$ & $32(5.4)$ & & $1(0.6)$ & $9(2.8)$ & & $2(0.9)$ & $8(2.8)$ & \\
\hline \multicolumn{10}{|l|}{ Laboratory services/ testing kits } \\
\hline Satisfied/Very Satisfied & $109(21.6)$ & $124(21.0)$ & 0.028 & $50(27.8)$ & $59(18.1)$ & 0.016 & $41(19.1)$ & $68(23.4)$ & 0.344 \\
\hline Neutral & $134(26.5)$ & $191(32.4)$ & & $48(26.7)$ & $86(26.5)$ & & $60(27.9)$ & $74(25.6)$ & \\
\hline Unsatisfied/ Very Unsatisfied & $248(49.1)$ & $243(41.3)$ & & $78(43.3)$ & $170(52.3)$ & & $111(51.6)$ & $137(47.2)$ & \\
\hline Don't know & $14(2.8)$ & $31(5.3)$ & & $4(2.2)$ & $10(3.1)$ & & $3(1.4)$ & $11(3.8)$ & \\
\hline \multicolumn{10}{|l|}{ Quarantine facilities } \\
\hline Satisfied/Very Satisfied & $134(26.6)$ & 157 (26.6) & 0.022 & $56(31.1)$ & $78(24.1)$ & 0.012 & $56(26.2)$ & $78(26.9)$ & 0.602 \\
\hline Neutral & $125(24.8)$ & $179(30.4)$ & & $50(27.8)$ & $75(23.1)$ & & $51(23.8)$ & $74(25.5)$ & \\
\hline Unsatisfied/ Very Unsatisfied & $228(45.2)$ & $223(37.9)$ & & $69(38.3)$ & $159(49.1)$ & & $103(48.1)$ & $125(43.1)$ & \\
\hline Don’t know & $17(3.4)$ & $30(5.1)$ & & $5(2.8)$ & $12(3.7)$ & & $4(1.9)$ & $13(4.5)$ & \\
\hline \multicolumn{10}{|l|}{ Personal Protective Equipment } \\
\hline Satisfied/Very Satisfied & $86(17.0)$ & $100(17.0)$ & $<0.001$ & $39(21.5)$ & $47(14.5)$ & 0.072 & $29(13.6)$ & $57(19.6)$ & 0.076 \\
\hline Neutral & $95(18.8)$ & $186(31.6)$ & & $38(21.0)$ & 57 (17.6) & & 37 (17.3) & $58(19.9)$ & \\
\hline Unsatisfied/ Very Unsatisfied & $311(61.6)$ & $268(45.5)$ & & $102(56.4)$ & $209(64.5)$ & & $144(67.3)$ & $167(57.4)$ & \\
\hline Don't know & $13(2.6)$ & $35(5.9)$ & & $2(1.1)$ & $11(3.4)$ & & $4(1.8)$ & $9(3.1)$ & \\
\hline
\end{tabular}

512 *Mann-Whitney test $\dagger$ Pearson Chi-square test

513 Note: Only the most salient variables have been reported in this table. Percentages of categories "satisfied" and "very satisfied" were

514 merged into category "satisfied/very satisfied", and categories "unsatisfied" and "very unsatisfied" were merged into

515 "unsatisfied/very unsatisfied". 